\title{
INORGANIC DOPANTS IN POLYMER CHOLESTERIC LIQUID CRYSTALS
}

\author{
Anka Trajkovska Petkoska \\ Faculty of Technology and Technical Sciences, Veles, \\ St. Kliment Ohridski University, Bitola, Republic of Macedonia \\ anka.trajkovska@uklo.edu.mk
}

\begin{abstract}
A variety of dopants are used for different types of polymers to change their properties. Inorganic dopants are normally used to change the dielectric properties of the polymers. These compositions find different applications, especially in electronic systems, due to the ease of polymer processing, increased functionality and the low cost of novel materials that are with relatively high dielectric constant compared to the base polymer material.

In this study, polymer cholesteric liquid crystal (PCLC) is used as a host material that is doped by different inorganic dopants, $\mathrm{BaTiO}_{3}$ and $\mathrm{TiO}_{2}$, all of which affect the dielectric constant of the polymer matrix. This is important from the fact that doped PCLC can be used for a variety of electro-optical applications, e.g. display applications and low energy consuming e-book application. The behavior of inorganic dopants in PCLC is calculated by various existing mixing models; the best fit is observed by the use of logarithmic equation.
\end{abstract}

Keywords: polymer cholesteric liquid crystals; inorganic dopants; $\mathrm{BaTiO}_{3} ; \mathrm{TiO}_{2}$

\section{НЕОРГАНСКИ ДОПАНТИ ВО ПОЛИМЕРНИ ХОЛИСТЕРИЧНИ ТЕЧНИ КРИСТАЛИ}

\begin{abstract}
Најразлични допанти се користени за промена на својствата на различни видови полимери. Неорганските допанти обично се користат за промена на диелектричните својства на полимерите. Овие композиции наоѓаат најразлични апликации, посебно во електронските системи, поради лесно процесирање на полимерот, зголемена функционалност и ниската цена на чинење на новите материјали кои се со релативно висока диелектрична константа споредено со основниот полимерен материјал.

Во овој труд полимерни холистерични течни кристали (PCLC) се користени како базен материјал кој е допиран со различни видови неоргански допанти, $\mathrm{BaTiO}_{3}$ и $\mathrm{TiO}_{2}$, коишто влијаат на диелектричната константа на полимерната матрица. Ова е важно од аспект дека допираниот PCLC може да се користи за најразлични електро-оптички апликации, како на пример, дисплеј апликации и е-книга (електронска книга), апликации кои имаат мала потрошувачка на енергија. Однесувањето на неорганските допанти во PCLC е пресметано со користење различни постојни модели на мешање. Се покажало дека најдобар модел е со користење на логаритамската равенка.
\end{abstract}

Клучни зборови: полимерни холистерични течни кристали; неоргански допанти; $\mathrm{BaTiO}_{3} ; \mathrm{TiO}_{2}$

\section{INTRODUCTION}

Composite materials obtained by integrating two or more materials can offer the potential to have performance far beyond those of the basic constituents. There are a variety of particulate sub- stances, such as metallic, ceramic, carbon, etc., that can be used as dopants (fillers, inclusions) in materials [1-7]. In particular, polymeric materials are of interest for doping with a variety of dopants and form composites with unique properties. Particle dopants can be of different shapes, such as spheri- 
cal [1, 2, 4], fiber-like [6], or flake-platelets and with dimensions from nano- $[2,6,8]$ to micronsized particles [1, 3, 4]. These heterogeneous mixtures exhibit improvements in their properties compared to those of the neat polymer host in terms of mechanical, electrical, and thermal properties, tailoring them to a variety of applications [1, 3, 6, 9-27].

To raise the dielectric constant of polymer materials, polymer composite materials provide an ideal solution. Ferroelectric ceramics as dopants to polymer hosts usually possess relatively high dielectric constants, but are brittle and have low dielectric strength. On the other hand, polymers are flexible, easy to process with low processing temperature in general, but possess high dielectric breakdown fields. By mixing polymers with ceramic dopants, a unique composite material can be obtained - high dielectric constant polymeric material. In general, the most commonly used polymers are epoxy, polyethylene, polypropylene, polyethylene therephtalate, poly-methyl metacrylate, and poly-ethyletherketone, which meet the requirements for the low cost organic substrate process and mechanical flexibility, and can be upgraded with the advantages from the fillers/dopants and obtaining desirable dielectric properties. They find a variety of applications, especially in electronic systems, due to the growing demands of electronic miniaturization or packaging, increased functionality, high performance and low cost for novel material compositions with high dielectric constants [28-45]. The dielectric properties of polymer compositions depend primarily on the content, size, and distribution of dopant particles as well as processing techniques. When very high dopant concentrations are required to increase the dielectric constant of the composite, processing can become more difficult; other properties, optical or physical, may also be disrupted.

Predicting or calculating the dielectric constant of the polymer composites resulting from doping is very important. For this purpose, different dielectric mixing models exist for prediction of the dielectric constant of heterogeneous mixtures [46-48]. The equations for the effective dielectric constant of the composite are generally based on the dielectric permittivity of each constituent and its volume fraction. The following models and equations are described by many other authors $[49,50]$.

Maxwell-Garnett mixture equation (1) is given as:

$$
\frac{\varepsilon_{m}-1}{\varepsilon_{m}+2}=f_{1} \frac{\varepsilon_{1}-1}{\varepsilon_{1}+2}+f_{2} \frac{\varepsilon_{2}-1}{\varepsilon_{2}+2},
$$

where $\varepsilon_{m}$ is the dielectric constant of the mixture, $\varepsilon_{1}$ and $\varepsilon_{2}$, are the dielectric constants, and $f_{1}$ and $f_{2}$ are volume fractions of each component (1 refers to the polymer or PCLC matrix, and 2 for dopant). Models for the effective dielectric constant of composites use the same notation.

The Bruggeman or the Bruggeman-Hanai equation is given as eq. (2). This equation is also known as the Botcher equation:

$$
f_{1} \frac{\varepsilon_{1}-\varepsilon_{m}}{\varepsilon_{1}+2 \varepsilon_{m}}+f_{2} \frac{\varepsilon_{2}-\varepsilon_{m}}{\varepsilon_{2}+2 \varepsilon_{m}}=0 .
$$

The two-phase mixture equation, denote as $M U$, is given in eq. (3):

$$
\varepsilon_{m}=\varepsilon_{1}\left[1+3\left(\frac{\varepsilon_{2}+2 \varepsilon_{1}}{f_{2}\left(\varepsilon_{2}-\varepsilon_{1}\right)}-1\right)^{-1}\right] \text {. }
$$

The Logarithmic or Lichtenecker-Rother [42] equation (4) is one of the most commonly used equations for predicting the dielectric constant of statistical/chaotic composites. It is given as:

$$
\log \varepsilon_{m}=f_{1} \log \varepsilon_{1}+f_{2} \log \varepsilon_{2} .
$$

For insulating fillers in a polymer, there is a Maxwell-Wagner mixing rule [48] formula that is given as eq. (5):

$$
\varepsilon_{m}=\varepsilon_{1}\left\{\frac{\left[2 \varepsilon_{1}+\varepsilon_{2}+2 f_{2}\left(\varepsilon_{2}-\varepsilon_{1}\right)\right]}{\left[2 \varepsilon_{1}+\varepsilon_{2}-2 f_{2}\left(\varepsilon_{2}-\varepsilon_{1}\right)\right]}\right\} \text {. }
$$

The above equations give similar results for lower dopant loading in a polymer host. For higher volume fractions of a dopant in a polymer, there are often discrepancies between these models and experimental data. This is possibly due to the following: a) the high volume fraction of the dopant may increase the porosity of the composite material, or b) the high dopant fraction may lead to agglomeration of the powder and a non-uniform distribution through the composite.

In this work, inorganic dopants, like different $\mathrm{BaTiO}_{3}$ and $\mathrm{TiO}_{2}$, are used and considered nonconductive (ceramic) dopants with high inherent dielectric constants. They increase the dielectric constant of polymers when they are added in large concentrations, without affecting conductivity. 
Polymer-ceramic materials, polymers doped with ferroelectric $\mathrm{BaTiO}_{3}$ (BT), offer the potential to have both the high dielectric constant due to the ceramic material (BT) and good polymer processing $[46,51]$. The dielectric properties mostly depend on: the content, purity, size, distribution of the BT particles and the processing techniques. Usually, very high dopant concentrations (more than 30 vol.\% or even higher $\sim 51$ vol.\% or 67 vol.\% ) are required to increase the real permittivity of the composite from an undoped value e.g. $~ 2$ (for the polymer host) to $\sim 100$ (for the polymer composition) [42, 46, 47, 51]. Sometimes this is not beneficial, because the high dopant loadings in the polymer host can make processing very difficult. Another problem which usually arises for BT is the difficulty in measuring the true value for the dielectric constant of the BT. There is no direct methodology for measuring the dielectric constant of dopants in powder form. Usually, the measured value of the dielectric constant for a bulk sample of BT ceramic is used instead of that for the powder form. The particle (grain) size of BT is very important for determining its dielectric constant. Literature values vary from 100-600 [48] (grain size $<0.7 \mu \mathrm{m}$, much smaller than the dielectric constant of bulk BT ceramics), to 2000 (for grain size of $10 \mu \mathrm{m}$, for example), or $\sim 5000$ (for grain size between 0.7 and $1 \mu \mathrm{m}$ ) [52]. The dielectric constant of these ceramic-polymer composites increases as the powder size decreases [37, 40-42, 45].

On the other hand, $\mathrm{TiO}_{2} /$ polymer composites are reported to exhibit improved mechanical properties, as well as increased dielectric constants; however, nano-sized $\mathrm{TiO}_{2}$ has a larger effect compared to micron-sized $\mathrm{TiO}_{2}$ on mechanical properties in $\mathrm{TiO}_{2}$ /polymer compositions $[10,11,43,45$, 54]. There are different crystalline forms of $\mathrm{TiO}_{2}$ powders, such as rutile and anatase. The rutile form of $\mathrm{TiO}_{2}$ has a higher dielectric constant than the anatase form, usually ranging from 20 to over 200 , but this value also depends on the compositeon/purity of $\mathrm{TiO}_{2}$ material (higher the amount of rutile phase means higher the dielectric constant of composition).

The PCLC material in this study was of the particular interest for the author, it possesses unique optical properties: selective reflection and circular polarization of the reflected light due to the helical structure $[45,55,56]$. As a result of its doping, the use of PCLC extends to novel optical, photonic and electronic applications. The most important are electro-optical applications, such as display and sensor applications, color filters, and electronic labels, besides the known passive applications such as use in the military as decals, decorative/cosmetic inks and paints, document security, retarders, waveplates, filters, polarizers, etc. [45, 56-60].

\section{EXPERIMENTAL}

\subsection{Materials}

The polymer cholesteric liquid crystal (PCLC) material used as a polymer matrix in this work is a non-cross-linkable cyclic polysiloxane material. It is left-handed cholesteric liquid crystal that belongs to the class of side-chain liquid crystalline polymers (product of Wacker-Chemie $\mathrm{GmbH}$, Munich, Germany) with a glass transition temperature $\sim 50{ }^{\circ} \mathrm{C}$ and a clearing point $\left(T_{c}\right)$ of $\sim 200{ }^{\circ} \mathrm{C}$ (as measured by the manufacturer and other researchers) [45]. PCLC exhibits unique optical properties, such as selective reflection and circular polarization due to its helical structure, and has the potential in many optical, photonic and electronic applications [45, 55-58]. Figure 1 shows PCLC material made into thin film (Fig. 1a) and into the form of tiny particles (flakes), irregular or regularly-shaped, presented in Figure $1 \mathrm{~b}$ and Figure $1 \mathrm{c}$.

Dopants considered in this work are listed in Table 1. They are $\mathrm{BaTiO}_{3}(\mathrm{BT})$ and $\mathrm{TiO}_{2}$ materials.

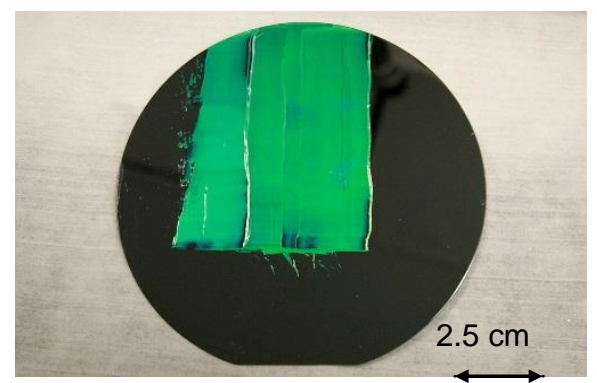

a)

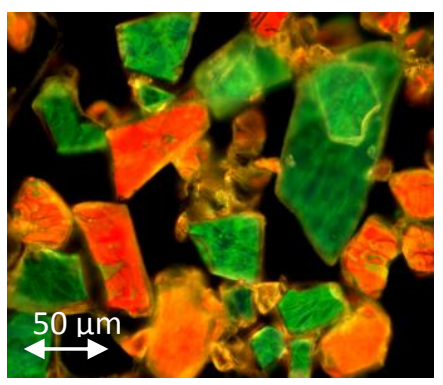

b)

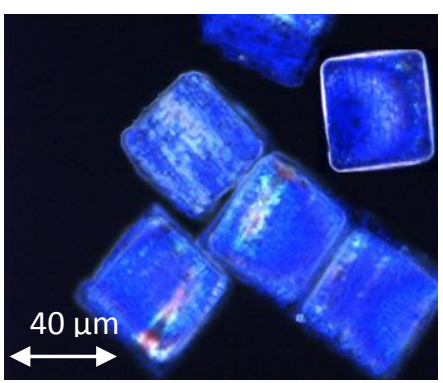

c)

Fig. 1. a) Thin PCLC film prepared on a silicon wafer substrate, b) irregularly shaped PCLC microparticles prepared by freezefracturing of the film with liquid nitrogen, c) tailored shaped blue PCLC microparticles prepared by soft-lithography technique [45]. 
Table 1

Dopants for PCLC used in this work

\begin{tabular}{|c|c|c|}
\hline Dopant & Particle size* & Particle shape \\
\hline $\begin{array}{l}\text { Neat PCLC } \\
\text { (no dopant) }\end{array}$ & - & \\
\hline \multicolumn{3}{|l|}{ Inorganic } \\
\hline $\mathrm{BaTiO}_{3}-1$ (BT-1) & $70 \mathrm{~nm}$ & spherical \\
\hline $\mathrm{BaTiO}_{3}-2(\mathrm{BT}-2)$ & 1 to $1.1 \mu \mathrm{m}$ & spherical \\
\hline $\mathrm{BaTiO}_{3}-3(\mathrm{BT}-3)$ & 1.3 to $1.8 \mu \mathrm{m}$ & spherical \\
\hline $\mathrm{TiO}_{2}-1$ & $30 \mathrm{~nm}$ & spherical \\
\hline $\mathrm{TiO}_{2}-2$ & $10 \mathrm{~nm} \times 40 \mathrm{~nm}$ & needle-like \\
\hline
\end{tabular}

${ }^{\text {a) }}$ Primary average particle dimensions

Namely, three different types of BT dopants and two of $\mathrm{TiO}_{2}$ with different particle sizes and shapes are used $[45,59,60]$. Nano- and microsized $\mathrm{BaTiO}_{3}$ powders were selected knowing that the dielectric constant of this type of dopant varies substantially with particle size. Two types of rutile type of $\mathrm{TiO}_{2}$ are investigated: one of them, $\mathrm{TiO}_{2}-1$, consists of particles with a spherical shape $(30 \mathrm{~nm}$ in diameter, product of Marketech International, Inc., Port Townsend, WA), while the other type, $\mathrm{TiO}_{2}-2$, are particles with needle-like shapes (dimension of $10 \mathrm{~nm}$ x $40 \mathrm{~nm}$, Nanostructured \& Amorphous Materials, Inc., Los Alamos, NM). [Note: these are primary particle dimensions. By SEM, it is determined that both of these powders are highly aggregated] [45]. The dielectric constant values of $\mathrm{TiO}_{2}$ dopants were not provided by the vendors; for theoretical calculations for $\varepsilon_{2}\left(\mathrm{TiO}_{2}\right)$ in this work, a value that varies from 20 to 200 was used.

\subsection{Measurement on PCLC/dopant composites}

Doped disks (pellets) made from PCLCs (product of Wacker-Chemie $\mathrm{GmbH}$, Munich, Germany) and a particular dopant were prepared in order to determine the dielectric properties of the compositions. Pellets made from pure dopant powder are not easily prepared because of their high melting temperatures or their inability to be compressed into pellets. For each system (PCLC/dopant), $\sim 10$ or more samples with different dopant concentrations are prepared with a diameter of $\sim 2$ $\mathrm{cm}$ and a thickness of $\sim 0.5 \mathrm{~mm}$ by using a "thin film-maker tool" with controlled heating and pressure (constant-thickness filmmaker and thin-filmmaking kits are products of International Crystal Laboratories, Garfield, NJ) [45].

Dielectric measurements of each PCLC/dopant composition as well as on pure PCLC disk are conducted on a frequency response analyzer by using a special holder for solids (Solartron 1260 by Solartron Analytical). These measurements are rapid, accurate and non-destructive, for electrochemical phenomena in materials. The sample holder for solids is designed to allow accurate impedance tests of solids at room temperature. It consists of two parallel electrodes that form a parallel capacitor. The bottom electrode is fixed in position, and the top electrode can be lowered into contact with the sample. After contact with the sample is made, a measurement of the sample thickness can be taken by reading the dial of a micrometer thickness gauge attached to the top electrode. The range of measured impedance values vary from 1 $\Omega$ to $100 \mathrm{~T} \Omega$ and the frequency region for measurement is from $10 \mu \mathrm{Hz}$ to $32 \mathrm{MHz}$. When a voltage (potential) is applied to the material, a current flows through the test chamber that is determined by the mechanisms characterizing the motion of charge within the material $[45,61,62]$. The output impedance signal after interaction with the sample presented as capacitance, $\mathrm{C}$, and resistance, $\mathrm{R}$, as a function of the frequency is analyzed by frequency response analysis (FRA) [63]. [Calculations of the dielectric properties of the measured samples placed in the parallel plate capacitor are performed by assumption of a circuit where $\mathrm{C}$ is in a parallel configuration with R] [45].

Scanning electron microscopy (SEM) micrographs are taken using either an FE SEM LEO 982 (EMSL, Richland, WA) and SEM LEO-EVO 50 , while polarized optical microscopy (POM) images are taken on a Leica, DMRX polarizing microscope coupled with a DC300F camera (Leica Microsystems AG, Germany) [45].

\section{RESULTS AND DISCUSSION}

All inorganic dopants used in this work show a similar effect on PCLC dielectric properties. They increase the dielectric constant of the composite at relatively high dopant loadings. The equations given in the Introduction predict that the dielectric constant of PCLC doped with BT and $\mathrm{TiO}_{2}$ can be increased only by a factor of $\sim 10$ or less at relatively high dopant level $\sim 25 \mathrm{vol} . \%$ or more. The best fit of experimental data are observed via equations 4 and 5 [45]. Table 2 presents measured dielectric constants of different PCLC/dopant composites. 
Table 2

\section{Measured data of different PCLC/dopant composites}

\begin{tabular}{lc}
\hline \hline Dopant & $\begin{array}{l}\text { Dielectric constant of } \\
\text { composition PCLC/dopant } \\
\text { at 10 kHz (at vol.\%) }\end{array}$ \\
\hline $\begin{array}{l}\text { Neat PCLC } \\
\text { (no dopant) }\end{array}$ & 2.1 \\
Inorganic & \\
\hline BaTiO $_{3}-1$ & $7.7(27.0)$ \\
$\mathrm{BaTiO}_{3}-2$ & $6.1(32.0)$ \\
$\mathrm{BaTiO}_{3}-3$ & $5.8(27.0)$ \\
$\mathrm{TiO}_{2}-1$ & $5.2(54.4)$ \\
$\mathrm{TiO}_{2}-2$ & $7.5(22.0)$ \\
\hline \hline
\end{tabular}

Figure 2a shows SEM images of doped PCLC particles with high doping levels of BT-1 (top and side view of the particles made of BT1/PCLC compositions), while Figure $2 b$ shows polarizing optical microscope (POM) images of BT-1 doped green PCLC particles. [It is noticeable that high BT concentrations in PCLC disrupt the selective reflection as well].
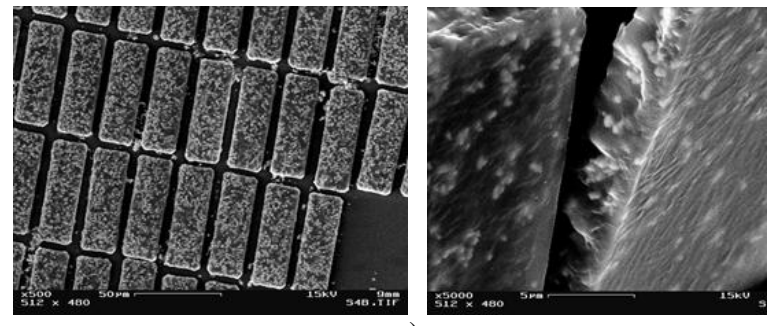

a)
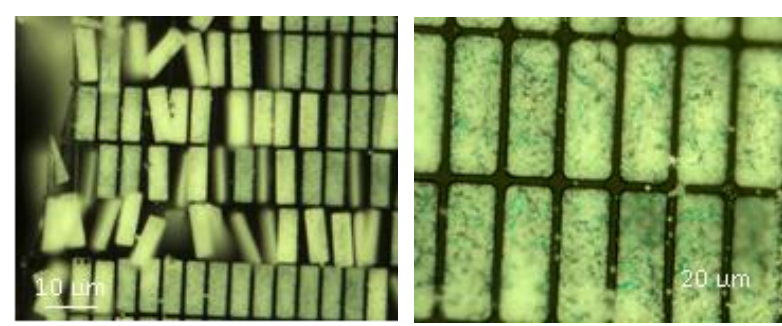

b)

Fig. 2. a) SEM images (top and side view of the particles made of 20 vol.\% BT-1 in PCLC), b) POM images of $\sim 20$ vol.\% BT-1-doped PCLC particles

Figure 3a) shows POM images of 20 vol. $\%$ $\mathrm{TiO}_{2}$-doped PCLC square-shaped particles. [These composites also exhibit a reduction in the quality of green selective reflection]. Figure $3 b$ compares the theoretical calculations for the effective dielectric constant of the $\mathrm{TiO}_{2} / \mathrm{PCLC}$ composite using eq. 4 and the experimental data for both $\mathrm{TiO}_{2}$ powders (listed in Table 1). The value for $\varepsilon_{2}\left(\mathrm{TiO}_{2}\right)$ varied from 20 to 200 (for the theoretical calculation using eq. 4) and the resulting values for the composite dielectric constant, $\varepsilon_{\mathrm{m}}$, vary from 4 to 12 at dopant level of 35 vol. $\% \mathrm{TiO}_{2}$ in PCLC composite. Experimental data for $\mathrm{TiO}_{2}-1$ are in better agreement with lower values for $\varepsilon_{2}$, e.g. 20-80, which suggests that this dopant powder is not purely rutile. $\mathrm{TiO}_{2}-2$ may be a purer rutile phase, since $\varepsilon_{\mathrm{m}}$ data fit better with the higher values of $\varepsilon_{2} \geq 200$ (e.g. at $\sim 25$ vol.\%, a dielectric constant of 8 is found for this composition).
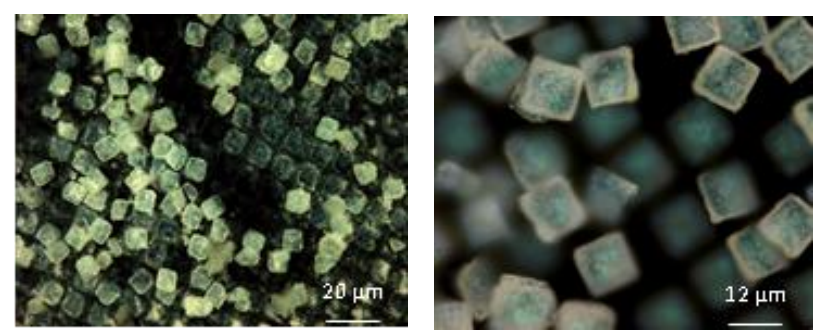

a)

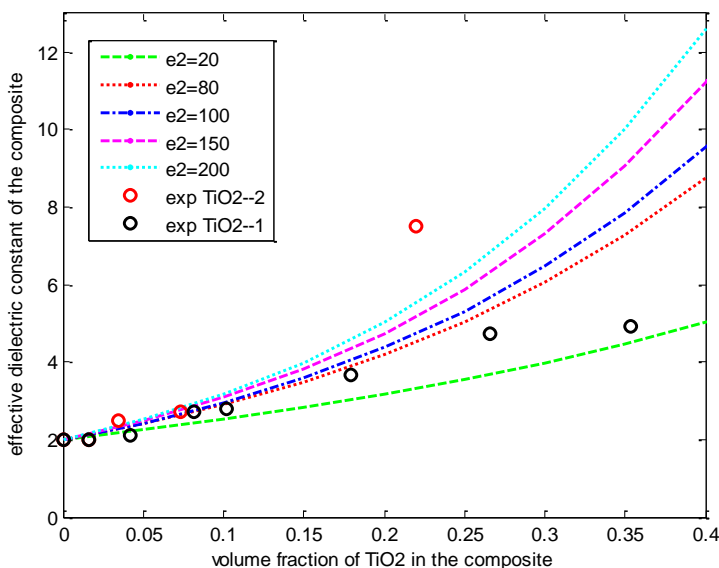

b)

Fig. 3. a) POM images of highly $\mathrm{TiO}_{2}$-doped PCLC particles, b) comparison of experimental data with theoretical calculations (using eq. 4) for effective dielectric constant for $\mathrm{TiO}_{2} / \mathrm{PCLC}$ mixtures for different values for $\varepsilon_{2}$ (Note: red and black circles in the graph are experimental data for $\mathrm{TiO}_{2}-2$ and $\mathrm{TiO}_{2}-1$ types of used dopants, respectively. Different colored lines are theoretical calculations that use different values of dopants' dielectric constant).

Figure 4 compares the effect of all inorganic $\mathrm{BaTiO}_{3}$ and $\mathrm{TiO}_{2}$ dopants in the PCLC matrix. Generally, all show an increase in composite dielectric constant up to ten at very high dopant levels, e.g., $\geq 20$ vol.\%. Higher dopant concentrations in PCLC are difficult to achieve. A logarithmic eq. 4 for calculation of the effective dielectric constant of the composite agrees well with the experimental data. The main problem here is choosing an appropriate value of the dopant dielectric constant to use in the model. In this case $\mathrm{PCLC} / \mathrm{BaTiO}_{3}$ composites are well fitted with the log equation (4) when $\varepsilon\left(\mathrm{BaTiO}_{3}\right)$ is $\sim 150$ (vendor supplied value is 150 
for $\mathrm{BaTiO}_{3}-1$ ), while the value used for $\mathrm{TiO}_{2}$ is $\varepsilon\left(\mathrm{TiO}_{2}\right) \sim 80$. Deviations between the experimental data and theoretical calculations can be due to: (a) the quality of dopant dispersion in the polymer matrix, (b) agglomeration, and/or (c) incorporation of air voids/pores inside the samples, which can drastically decrease the effective dielectric constant of the mixture, $\varepsilon_{m}$.

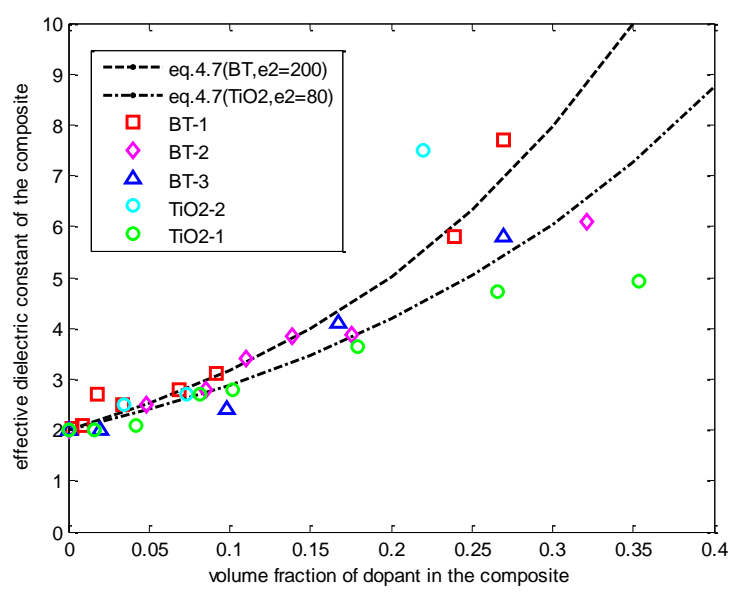

Fig. 4. Comparison of dielectric constant at $10 \mathrm{kHz}$ for PCLC composites using inorganic dopants $\mathrm{BaTiO}_{3}$ and $\mathrm{TiO}_{2}$, measured (symbols) vs. calculated (lines) values. Calculated values are obtained by use of logarithmic equation (4).

\section{CONCLUSION}

Ceramic-polymer composites have been investigated for different purposes. These composites have increased dielectric constants compared to the dielectric constant of basic polymer host, with or without increased composite conductivity. Finer inorganic particles (e.g. nano-particles) with a higher ratio of surface area to volume may have better particle-to-particle contact to improve the dielectric constant, dielectric loss, and insulation resistance. As a result, the ceramic-polymer composites have the smallest diameter of inorganic particles, and higher values of dielectric constant.

In this study, dopants like, $\mathrm{BaTiO}_{3}$ and $\mathrm{TiO}_{2}$ in PCLC material were investigated and shown to increase the dielectric constant of PCLC composites. Both dopants showed similar behavior. Namely, all three types of $\mathrm{BaTiO}_{3}$ had almost the same effect on the PCLC composite dielectric constant. $\mathrm{TiO}_{2}-2$ or a dopant with needle-like particles is more effective than the spherical $\mathrm{TiO}_{2}-1$ dopant. It is possible that $\mathrm{TiO}_{2}-1$ consists of mix rutile/ anatase phase material that would lower the dielectric constant compared to dielectric constant of $\mathrm{TiO}_{2}-2$. However, both dopant types used in this work for PCLC compositions fit well with the equations established by various authors. The best fit of these experimental data was observed with logarithmic equation.

Acknowledgments. This work was done at the University of Rochester, Laboratory for Laser Energetics in Rochester, NY, USA. The author thanks Prof. Steve D. Jacobs for his guidance and supervision through this project, and Mr. Kenneth Marshall and Dr. Tanya Kosc for their constructive advice and help. The author also acknowledges the Laboratory for Laser Energetics for Horton Fellowship support.

\section{REFERENCES}

[1] A. Maaroufi, K. Haboubi, A. El Amarti, F. Carmona, Electrical resistivity of polymeric matrix loaded with nickel and cobalt powders, Journal of Materials Science 39(1), 265-270 (2004).

[2] D. M. Grannan, J. C. Gargland, D. B. Tanner, Critical behavior of the dielectric constant of a random composite near the percolation threshold, Physical Review Letters 46(5), 375-378 (1981).

[3] H. Zois, L. Apekis, Y. P. Mamunya, Structureelectrical properties relationships of polymer composites filled with Fe-powder, Macromolecular Symposia 194, 351-359 (2003).

[4] H. Zois, Y. P. Mamunya, L. Apekis, Structure and dielectric properties of a thermoplastic blend containing dispersed metal, Macromolecular Symposia 198, 461-472 (2003).

[5] F. Carmona, Conducting Filled Polymers, Physica A 157(1), 461-469 (1989).

[6] M. Moniruzzaman, K. I. Winey, Polymer nanocomposites containing carbon nanotubes, Macromolecules 39(16), 5194-5205 (2006).

[7] Y. Xi, H. Ishikawa, Y. Z. Bin, M. Matsuo, Positive temperature coefficient effect of LMWPEUHMWPE blends filled with short carbon fibers, Carbon 42(8-9), 1699-1706 (2004).

[8] T. W. Ebbesen, Carbon Nanotubes, Annual Review of Materials Science 24, 235-264 (1994).

[9] R. Schueler, J. Petermann, K. Schulte, H. P. Wentzel, Agglomeration and electrical percolation behavior of carbon black dispersed in epoxy resin, J. App. Poly. Sci. 63(13), 1741-1746 (1997).

[10] Y. Lu, W. H. Lee, H. S. Lee, Y. Jang, K. Cho, Low-voltage organic transistors with titanium oxide/polystyrenebilayer dielectrics, Applied Physics Letters 94, 113303 (2009).

[11] S. Chaudhari, T. Shaikh, P. Pandey, A Review on Polymer $\mathrm{TiO}_{2}$ Nanocomposites, Int. J. Eng. Res. Appl. 3(5), 1386-1391 (2013).

[12] E. Tuncer, G. Polizos, D. R. James, I. Sauers, A. R. Ellis, K. L. More, Dielectric properties of various nanocomposite materials, CP1219 Advances in Cryogenic Engineering: Transactions of the Cryogenic Engineering Materials Conference-ICMC 
56, U. Balachandran (Ed), American Institute of Physics, 2010.

[13] W. Ling, Q. Xia, L. Yan, C. Wang, M. Cao, L. Liu, Preparation, Morphology and Dielectric Properties of Nano-TiC/Polyimide Composite Films, Polymers \& Polymer Composites, 22(2), (2014).

[14] C. Huang, Q. M. Zhang, High-dielectric-constant all-polymer percolative composites, Applied Physics Letters 82 (20), (2003).

[15] X. Huang, P. Jiang, L. Xie, Ferroelectric polymer/silver nanocomposites with high dielectric constant and high thermal conductivity, Applied Physics Letters 95, 242901 (2009).

[16] K. Shehzad, A. Ul-Haq, S. Ahmad, M. Mumtaz, T. Hussain, A. Mujahid, A. Tufail Shah, M. Y. Choudhry, I. Khokhar, S. Ul-Hassan, F. Nawaz, F. Rahman, Y. Butt, M. Pervaiz, All-organic PANIDBSA/PVDF dielectric composites with unique electrical properties, J. Mater. Sci. 48, 3737-3744 (2013).

[17] J. Xu, C. P. Wong, Effect of the Polymer Matrices on the Dielectric Behavior of a Percolative high kPolymer Composite for Embedded Capacitor Application, Journal of Electronic Materials 35(5), 1087 (2006).

[18] X. J. Wang, The effect of the prismatic filler arrangement and cross-sectional shape on the thermal conductivity of polymer composites, eXPRESS Polymer Letters 8 (12), 920-931 (2014).

[19] H. T. Oyama, M. Sekikawa, Y. Ikezawa, Influence of the Polymer/Inorganic Filler Interface on the Mechanical, Thermal, and Flame Retardant Properties of Polypropylene/Magnesium Hydroxide Composites, Journal of Macromolecular Science, Part B: Physics, 50, 463-483 (2011).

[20] M. Madani, Conducting carbon black filled NR/IIR blend vulcanizates: Assessment of the dependence of physical and mechanical properties and electromagnetic interference shielding on variation of filler loading, J. Polym. Res. 17, 53-62 (2010).

[21] X. Jin, M. Deng, S. Kaps, X. Zhu, I. Holken, K. Mess, R. Adelung, Y. K. Mishra, Study of Tetrapodal ZnO-PDMS Composites: A Comparison of Fillers Shapes in Stiffness and Hydrophobicity Improvements, PLOS ONE 9 (9), e106991 (2014).

[22] A. Ghosh, L. Ma, C. Gao, Zeolite molecular sieve $5 \mathrm{~A}$ acts as a reinforcing filler, altering the morphological, mechanical, and thermal properties of chitosan, J. Mater. Sci., 48, 3926-3935 (2013).

[23] V. Mittal, Modelling and Prediction of Barrier Properties of Polymer Layered Silicate Nanocomposites, Polymers \& Polymer Composites 21(8), (2013).

[24] L. Lee, I.-J. Kim, S. Yang, S. Kim, Electrochemical properties of PEO/PMMA blend-based polymer electrolytes using imidazolium salt-supported silica as a filler, Res. Chem. Intermed., 39, 32793290 (2013).
[25] Aga and $\mathrm{Mu}$, Doping of Polymers with $\mathrm{ZnO}$ Nanostructures for Optoelectronic and Sensor Applications, Nanowires Science and Technology, Nicoleta Lupu (Ed.), ISBN: 978-953-7619-89-3, InTech, 205-222 (2010).

[26] M. Johlitz, S. Diebels, Effective Mechanical Behavior of Filled Polymers, Mechanics of Advanced Materials and Structures 18, 106-114 (2011).

[27] J. L. Alan kin-tak Lau, Multifunctional Polymer Nanocomposites, Taylor and Francis Group, LLC, 2011.

[28] T. Hanemann, J. Boehm, P. Henzi, K. Honnef, K. Litfin, E. Ritzhaupt-Kleissl, J. Hausselt, From micro to nano: properties and potential applications of micro- and nano-filled polymer ceramic composites in microsystem technology, IEE Proc.Nanobiotechnol., 151(4), (2004).

[29] J. Lu, C. P. Wong, Recent Advances in High-k Nanocomposite Materials for Embedded Capacitor Applications, IEEE Transactions on Dielectrics and Electrical Insulation 15(5), (2008).

[30] J. Lu, K.-S. Moon, J. Xu, C. P. Wong, Synthesis and dielectric properties of novel high-K polymer composites containing in-situ formed silver nanoparticles for embedded capacitor applications, $J$. Mater. Chem., 16, 1543-1548, (2006).

[31] J. Xu, L. Wang, G. Liang, L. Wang, X. Shen, A General Quantitative Structure-Property Relationship Treatment for Dielectric Constants of Polymers, Poly. Eng. Sci. 51, 12 (2011).

[32] Q. M. Zhang, H. Li, M, Poh, Feng Xia, Z.-Y. Cheng, H. Xu, C. Huang, An all-organic composite actuator material with a high dielectric constant, Nature 419, (2002).

[33] K. Müller, I. Paloumpa, K. Henkel, D. Schmeisser, A polymer high- $k$ dielectric insulator for organic field-effect transistors, J. Appl. Phys. 98, 056104, (2005).

[34] T. Lei, Q. Xue, L. Chu, Z. Han, J. Sun, F. Xia, Z. Zhang, Q. Guo, Excellent dielectric properties of polymer composites based on core-shell structured carbon/silica nanohybrid, Appl. Phys. Lett. 103, 012902 (2013).

[35] Y. Bai, Z.-Y. Cheng, V. Bharti, H. S. Xu, Q. M. Zhang, High-dielectric-constant ceramic-powder polymer composites, Appl. Phys. Lett., 76(25), (2000).

[36] G. Subodh, V. Deepu, P. Mohanan, M. T. Sebastian, Dielectric response of high permittivity polymer ceramic composite with low loss tangent, Appl. Phys. Lett. 95, 062903 (2009).

[37] J.-R. Yoon, J.-W. Han, K.-M. Lee, Dielectric Properties of Polymer-ceramic Composites for Embedded Capacitors, Transactions on electrical and electronic materials 10(4), (2009).

[38] P. Thomas, S. Satapathy, K. Dwarakanath, K. B. R. Varma, Dielectric properties of poly(vinylidene 
fluoride) $/ \mathrm{CaCu}_{3} \mathrm{Ti}_{4} \mathrm{O}_{12}$ nanocrystal composite thick films, eXPRESS Polymer Letters 4(10), 632-643 (2010).

[39] V. Tomer, C. A. Randall, High field dielectric properties of anisotropic polymer-ceramic composites, $J$. Appl. Phys. 104, 074106, (2008).

[40] Y. Kobayashi, A. Kurosawa, D. Nagao, M. Konno, Fabrication of Barium Titanate NanoparticlesPolymethylmethacrylate composite films and their dielectric properties, Poly. Eng. Sci. 49, 6 (2009).

[41] M. Konieczna, E. Markiewicz, J. Jurga, Dielectric Properties of Polyethylene Terephthalate/Polyphenylene sulfide/barium titanate nanocomposite for application in electronic industry, Poly. Eng. Sci. 50, 8 (2010).

[42] R. K. Goyal, V. V. Madav, P. R. Pakankar, S. P. Butee, Fabrication and Properties of Novel Polyetheretherketone/Barium Titanate Composites with Low Dielectric Loss, J. Electr. Mat. 40(11), (2011).

[43] Y. I. Yua, M. H. Yia, T. Ahnb, Synthesis and characterization of a novel polyimide/ $/ \mathrm{TiO}_{2}$ nanocomposite for solution processable high $\mathrm{k}$ dielectric, J. Ceram. Proc. Res. 13(2), 202-205 (2012).

[44] P. Barber, S. Balasubramanian, Y. Anguchamy, S. Gong, A. Wibowo, H. Gao, H. J. Ploehn, H.-C. zur Loye, Polymer Composite and Nanocomposite Dielectric Materials for Pulse Power Energy Storage, Materials 2, 1697-1733 (2009).

[45] A. Trajkovska Petkoska, Polymer Cholesteric Liquid Crystal Flakes - their Electro Optic-Behaviour for Potential E-Paper Application, Verlag Dr. Müller, VDM ISBN 978-3-639-06439-1, Germany, 2008.

[46] C. K. Chiang, R. Popielarz, Polymer composites with high dielectric constant, Ferroelectrics 275 , $1-9$ (2001).

[47] L. Ramajo, M. Reboredo, M. Castro, Dielectric response and relaxation phenomena in composites of epoxy resin with $\mathrm{BaTiO}_{3}$ particles, Composites: Part A: Appl. Sci. Manu. 36(9), 1267-1274 (2005).

[48] S. D. Cho, S. Y. Lee, J. G. Hyun, K. W. Paik, Comparison of theoretical predictions and experimental values of the dielectric constant of epoxy/ $\mathrm{BaTiO}_{3}$ composite embedded capacitor films, $J$. Mat. Sci. - Mat. Electr. 16(2), 77-84 (2005).

[49] H. M. Musal, H. T. Hahn, G. G. Bush, Validation of Mixture Equations for Dielectric-Magnetic Composites, J. Appl. Phys. 63(8), 3768-3770 (1988).

[50] M. R. Anantharaman, S. Sindhu, S. Jagatheesan, K. A. Malini, P. Kurian, Dielectric properties of rubber ferrite composites containing mixed ferrites, J. Phys. D - Appl. Phys. 32(15), 1801-1810 (1999).

[51] R. Popielarz, C. K. Chiang, R. Nozaki, J. Obrzut, Dielectric properties of polymer/ferroelectric ce- ramic composites from $100 \mathrm{~Hz}$ to $10 \mathrm{GHz}, \mathrm{Mac}$ romolecules 34(17), 5910-5915 (2001).

[52] M. T. Buscaglia, V. Buscaglia, M. Viviani, J. Petzelt, M. Savinov, L. Mitoseriu, A. Testino, P. Nanni, C. Harnagea, Z. Zhao, M. Nygren, Ferroelectric properties of dense nanocrystalline $\mathrm{BaTiO}_{3}$ ceramics, Nanotechnology 15(9), 1113-1117 (2004).

[53] T. M. Shaw, S. Trolier-McKinstry, P. C. McIntyre, The properties of ferroelectric films at small dimensions, Ann. Rev. Mat. Sci. 30, 263-298 (2000).

[54] C. B. Ng, L. S. Schadler, R. W. Siegel, Synthesis and mechanical properties of $\mathrm{TiO}_{2}$-epoxy nanocomposites, Nanostructured Materials 12(1-4), 507-510 (1999).

[55] A. Trajkovska-Petkoska, R. Varshneya, T. Z. Kosc, K. L. Marshall, S. D. Jacobs, Enhanced ElectroOptic Behavior for Shaped Polymer Cholesteric Liquid Crystal (PCLC) Flakes Made by Soft Lithography, Adv. Funct. Mater., 15, 217 (2004).

[56] A. Trajkovska-Petkoska, S. D. Jacobs, The Manufacture, characterization, and manipulation of polymer cholesteric liquid crystal flakes and their possible applications, J. Mat. Sci. Eng. (A\&B), A2 2, 137-151 (2012)

[57] A. Trajkovska-Petkoska, Polymer cholesteric liquid crystal flakes as new candidates for display and sensor applications, NATO Science for Peace and Security Series-B: Physics and Biophysics: Nanotechnological Basis for Advanced Sensors, Springer, 2011.

[58] T. Z. Kosc, K. L. Marshall, A. TrajkovskaPetkoska, E. Kimball, S. D. Jacobs, Progress in the Development of Polymer Cholesteric Liquid Crystal Flakes for Display Applications, Displays 25, 171-176 (2004).

[59] A. Trajkovska-Petkoska, S. D. Jacobs, Effect of Different Dopants on Polymer Cholesteric Liquid Crystals, Mol. Cryst. Liq. Cryst., 495, 334 (2008).

[60] A. Trajkovska-Petkoska, S. D. Jacobs, K. L. Marshall, T. Z. Kosc, Electrically Actuated Doped Polymer Flakes and Electrically Addressable Optical Devices Using Suspensions of Doped Polymer Flakes in a Fluid Host, U.S. 7,713,436 B1 (2010).

[61] N. D. Cogger, N. J. Evans, An introduction to electrochemical impedance measurement, Technical report, No. 6, Solartron Analytical (1999).

[62] Standard test methods for AC loss characteristics and permittivity (dielectric constant) of solid electrical insulation, Designation D 150-95, ASTM Standard.

[63] P. E. Wellstead, Frequency response analysis, Technical report 10, Solartron Analytical, Control System Principles, Cheshire, UK (2003). 